\title{
Behaviour of Solid Oxide Fuel Cell Materials in Technological Environments
}

Viktoriya Podhurska ${ }^{a^{*}}$, Bogdan Vasyliv ${ }^{\mathrm{a}}$, Andrij Ivasyshyn ${ }^{\mathrm{a}}$, Orest Ostash ${ }^{\mathrm{a}}$, Oleksandr Vasylyev ${ }^{\mathrm{b}}$, Tetyana Prikhna ${ }^{\mathrm{c}}$, Volodymyr Sverdun $^{\mathrm{c}}$, Yehor Brodnikovskyi ${ }^{\mathrm{b}}$

${ }^{a}$ H.Karpenko Physico-Mechanical Institute, 5 Naukova Street, Lviv 79060, Ukraine

${ }^{\mathrm{b}}$ I.Frantsevich Institute for Problems in Materials Science, 3 Krzhizhanovsky Street, Kyiv 03680, Ukraine

${ }^{c}$ V.Bakul Institute for Superhard Materials, 2 Avtozavodska Street, Kyiv 04074, Ukraine podhurskavika@gmail.com

Keywords: solid oxide fuel cell (SOFC), YSZ-NiO anode ceramics, MAX-phase interconnect, reducing and oxidizing gas environments, physical and mechanical properties, structure.

The YSZ-NiO ceramics for SOFC anodes and MAX-phases of Ti-Al-C systems for interconnects have been investigated. Based on the tests of YSZ-NiO specimens preconditioned by one-time reduction or by redox cycling at 600 or $800{ }^{\circ} \mathrm{C}$, a certain mode of the material treatment was established which provides its improved physicomechanical properties. The oxidation behaviour of MAX-phases has been investigated at $600{ }^{\circ} \mathrm{C}$ in air. It was found that the intense initial oxidation of hot-pressed $\mathrm{Ti}_{3} \mathrm{AlC}_{2}$-based material can be eliminated by a certain mode of pre-oxidation. The oxidation resistance of the material can be significantly improved by niobium addition.

\section{Introduction}

A number of publications predict a dual influence of operating temperature on resulting physical and mechanical properties of the Nicontaining anode material for solid oxide fuel cells (SOFCs) after cyclic reduction-oxidation (redox) treatment [1-3]. It is well known that the electrical conductivity of metallic $\mathrm{Ni}$ (of about $1.4 \cdot 10^{7} \mathrm{~S} / \mathrm{m}$ ) is much higher than that of YSZ-Ni cermet. According to our data, after exposition of the ceramics sintered of $\mathrm{NiO}$ powder, for $4 \mathrm{~h}$ or more in pure hydrogen at $600{ }^{\circ} \mathrm{C}$, complete reduction can be achieved [4].
The resulting electrical conductivity of the material is about $(1-5) \cdot 10^{6} \mathrm{~S} / \mathrm{m}$. However, exposition of $\mathrm{NiO}$ ceramics at this regime in the Ar-5 vol $\% \mathrm{H}_{2}$ mixture that can be used for gradual reduction of SOFC anodes causes partial reduction of the $\mathrm{NiO}$ particles forming thin edgings of metallic $\mathrm{Ni}$ (of thickness of $0.1-$ $0.3 \mu \mathrm{m}$ ) around them. Thus, the electrical conductivity of the material treated is in the range of $(1-5) \cdot 10^{5} \mathrm{~S} / \mathrm{m}$ depending on average particle size, porosity and resulting contacts between Ni edgings. During redox treatment of $\mathrm{NiO}$ ceramics, structural transformation of 
boundaries of contacting nickel phase particles occurs, causing an increase in strength.

In our previous works, it was revealed for ScCeSZ-NiO anode ceramics that at selected redox treatment regimes when the material is heated in vacuum and intermediate degassing between reduction and oxidation stages is performed, substantial improvements in strength (up to $112 \%$ ) and electrical conductivity can be reached at the treatment temperature of $600{ }^{\circ} \mathrm{C}[5,6]$.

Recently, a new classes of materials based on layered carbide $\mathrm{Ti}_{3} \mathrm{AlC}_{2}$ have attracted a great attention of material scientists due to their exceptional properties. This carbide belongs to so called MAX-phases which have a chemical formula: $M_{n+1} A X_{n}$ - where $M$ is an early transition metal, $\mathrm{A}$ is an A-group element, and $\mathrm{X}$ is carbon and/or nitrogen. These materials have good thermal and electrical conductivity, low density, high strength and Young's modulus, excellent thermal shock resistance, high chemical resistance, relatively low thermal expansion coefficient and good machinability [7-9]. Owing to such combination of properties they have been suggested for various application, especially as high-temperature structural materials. This requires comprehensive investigations of oxidation resistance of $\mathrm{Ti}_{3} \mathrm{AlC}_{2}$ based materials.

In spite of thorough research of oxidation behavior of $\mathrm{Ti}_{3} \mathrm{AlC}_{2}$ based materials at high temperature [10-13], only a few results obtained at intermediate temperatures have been reported $[14,15]$. Take into account the anomalously intense oxidation of $\mathrm{Ti}_{3} \mathrm{AlC}_{2}$ based material at $500{ }^{\circ} \mathrm{C}$ and specially at $600{ }^{\circ} \mathrm{C}$ [14] the investigation of oxidation behavior of these materials at intermediate temperatures have a great importance.

The aims of this work are to study the physical and mechanical behaviour of the SOFC anode and interconnect material and to find out the microstructural changes causing resulting properties of the material.

\section{Experimental part}

\section{Materials}

Anode ceramics of the YSZ-NiO system sintered at Forschungszentrum Jülich (Germany) of zirconium oxide powder stabilized with $8 \mathrm{~mol} \% \mathrm{Y}_{2} \mathrm{O}_{3}$, with the addition of $50 \mathrm{wt} \% \mathrm{NiO}$, has been investigated.

The interconnect materials used in this work were initially sintered in vacuum from mixture of $\mathrm{TiC}, \mathrm{TiH}_{2}$ and $\mathrm{Al}$ powders and then hot pressed at $1350{ }^{\circ} \mathrm{C}$ under pressure of $30 \mathrm{MPa}$ for $1 \mathrm{~h}$. The phase composition of sintered material consisted of $95 \mathrm{wt} . \% \mathrm{Ti}_{3} \mathrm{AlC}_{2}$ and 5 wt. $\%$ TiC. Fig. la shows the backscattered electron image of polished surface of this material. The equi-axed grains of $\mathrm{Ti}_{3} \mathrm{AlC}_{2}$, fine particles of $\mathrm{TiC}$ and big pores were observed. The porosity of the material determined by the hydrostatic-weighing method was $22 \%$. After hot pressing refinement of the 
structure and reducing of the porosity to $1 \%$ have been occurred (Fig. 1b). The amount of $\mathrm{Ti}_{3} \mathrm{AlC}_{2}$ was decreased to 92 wt. $\%$ and $\mathrm{TiC}$ increased to $6 \mathrm{wt} . \%$. Additionally, in this material we revealed the 2 wt. $\% \mathrm{Al}_{2} \mathrm{O}_{3}$. The material doped with $3.5 \mathrm{wt}$. \% Nb fabricated by the same process as previous material consisted of 56 wt. \% (Ti, $\mathrm{Nb})_{3} \mathrm{AlC}_{2}, 41$ wt. \% $\mathrm{TiC}$ and 3 wt. $\% \mathrm{Al}_{2} \mathrm{O}_{3}$. The structure of this material includes equi-axed grains of $\mathrm{Ti}_{3} \mathrm{AlC}_{2}$ and $\mathrm{TiC}$ and uniformly distributed fine particles of $\mathrm{Al}_{2} \mathrm{O}_{3}$ and small pores (Fig. 1c).

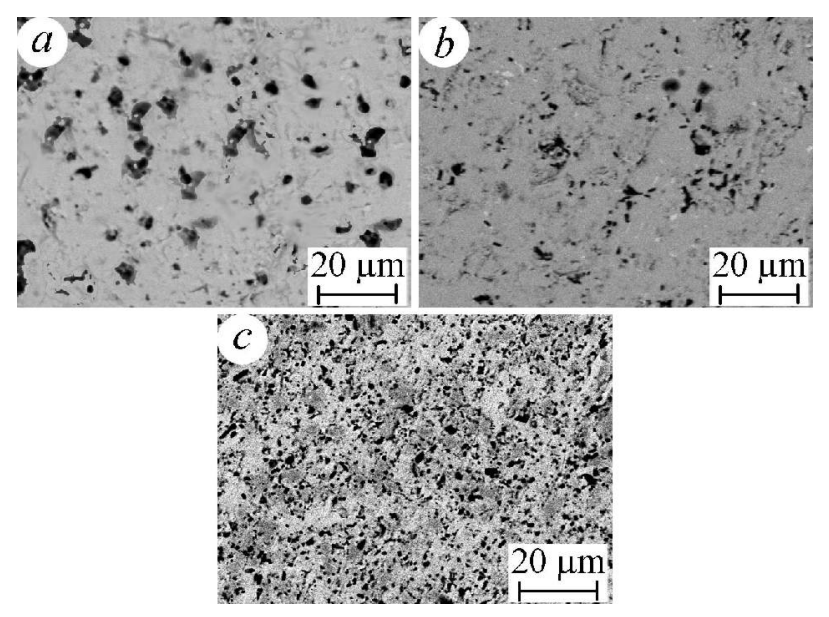

Figure 1. Back-scattered electron images of the polished surfaces: (a) $\mathrm{Ti}_{3} \mathrm{AlC}_{2}$ based material with $22 \%$ porosity;

(b) $\mathrm{Ti}_{3} \mathrm{AlC}_{2}$ based material with $1 \%$ porosity and (c) $\mathrm{Nb}$ dopped $\mathrm{Ti}_{3} \mathrm{AlC}_{2}$ based material with $1 \%$ porosity.

\section{Methods}

A series of YSZ-NiO ceramic specimens of the size of $1 \times 5 \times 25 \mathrm{~mm}$ were singly reduced at 600 or $800{ }^{\circ} \mathrm{C}$ in a hydrogenous environment (the $\mathrm{Ar}-5$ vol\% $\mathrm{H}_{2}$ mixture or hydrogen of 99.99 vol\% $\mathrm{H}_{2}$ purity) under the pressure of $0.15 \mathrm{MPa}$ (Fig. 2a) or subjected to redox cycling (see Table 1) [16].
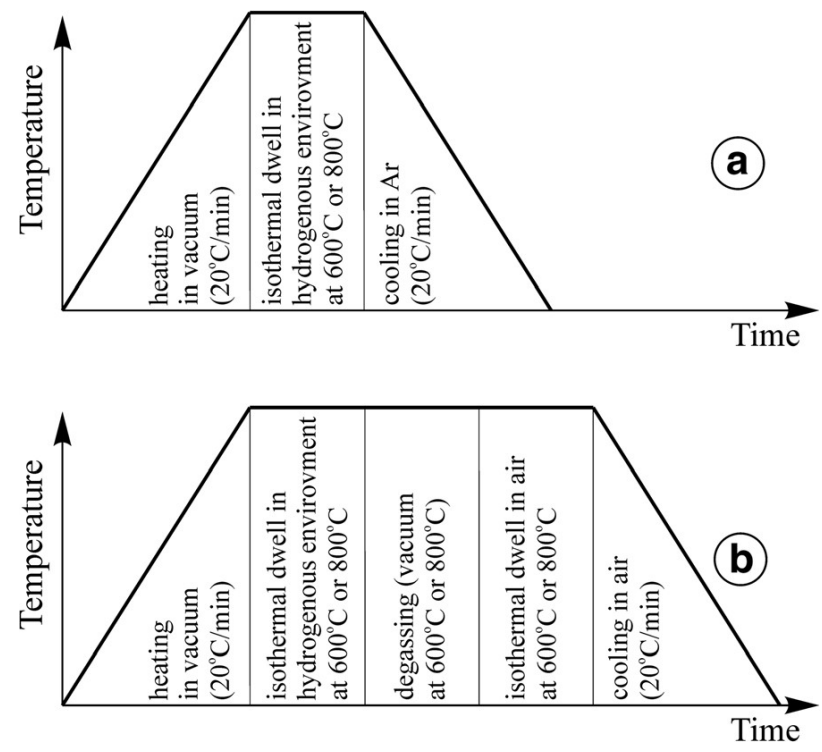

Figure 2. The treatment schemes applied for YSZ-NiO ceramics. a Single reduction in a hydrogenous environment. b A cycle of redox treatment.

The redox treatment of ceramics was performed for five cycles according to the scheme [4]: heating in vacuum from 20 to $600{ }^{\circ} \mathrm{C}$, reduction in a hydrogenous environment at 600 or $800{ }^{\circ} \mathrm{C}$ under the pressure of $0.15 \mathrm{MPa}$, degassing, oxidation in air at $600{ }^{\circ} \mathrm{C}$ and cooling down to $20{ }^{\circ} \mathrm{C}$ in air (Fig. 2b). Reduction/oxidation stage duration was chosen, taking into account the literature data on complete or partial reduction of the material [17]. After the redox cycling, reduction of materials in a hydrogenous environment for 4 $\mathrm{h}$ at $600{ }^{\circ} \mathrm{C}$ or for $1 \mathrm{~h}$ at $800{ }^{\circ} \mathrm{C}$ under the pressure of $0.15 \mathrm{MPa}$ with cooling in argon was performed (see the scheme in Fig. 2a) [16]. The heating/cooling rate was $20^{\circ} \mathrm{C} / \mathrm{min}$.

Table 1. The treatment regimes for the materials tested 


\begin{tabular}{|l|l|l|l|l|}
\hline $\begin{array}{l}\text { No. of } \\
\text { version }\end{array}$ & Environment & $\begin{array}{l}\text { Treatment } \\
\text { temperature } \\
\left({ }^{\circ} \mathrm{C}\right)\end{array}$ & $\begin{array}{l}\text { Reduction/ } \\
\text { oxidation } \\
\text { stage } \\
\text { duration } \\
(\mathrm{h})\end{array}$ & $\begin{array}{l}\text { Variant } \\
\text { of } \\
\text { treatment }\end{array}$ \\
\hline 1 & $\mathrm{Ar}-\mathrm{H}_{2}$ mixture & 600 & 4 & $\mathrm{R}$ \\
\hline 2 & $\mathrm{H}_{2}$ & 600 & 4 & $\mathrm{R}$ \\
\hline 3 & $\begin{array}{l}\mathrm{Ar}-\mathrm{H}_{2} \text { mixture } \\
\text { air }\end{array}$ & 600 & 4 & $\mathrm{RO}$ \\
\hline 4 & $\mathrm{H}_{2} /$ air & 600 & 4 & $\mathrm{RO}$ \\
\hline 5 & $\mathrm{Ar}-\mathrm{H}_{2}$ mixture & 800 & 1 & $\mathrm{R}$ \\
\hline 6 & $\begin{array}{l}\mathrm{Ar}-\mathrm{H}_{2} \text { mixture } \\
/ \text { air }\end{array}$ & 800 & 1 & $\mathrm{RO}$ \\
\hline
\end{tabular}

$\mathrm{R}$ single reduction, $\mathrm{RO}$ redox cycling

The isothermal oxidation tests of interconnect materials were carried out at the temperature of $600{ }^{\circ} \mathrm{C}$ in static air using rectangular bars with dimensions of $20 \times 5 \times 3 \mathrm{~mm}$. The specimens were cut by the electrical discharge method, abraded to 1000 grit with SiC paper and polished by diamond past. The oxidation tests were divided into five stages which had the duration: first stage $-15 \mathrm{~h}$, second stage $-245 \mathrm{~h}$ and the last three stages $250 \mathrm{~h}$. The each stage consisted of heating to $600^{\circ} \mathrm{C}$ in air, exposition for determinated time and cooling to room temperature. The weight of the specimens was measured before the test and after the each stage by analytical balance. The accuracy of the weight measuring was $\pm 10^{-4} \mathrm{~g}$. The oxidation resistance of materials tested was characterized by weight gain per unit surface area $\Delta \mathrm{W} / \mathrm{S}$.

Ultimate fracture stresses of materials in the initial state $\left(\sigma_{\mathrm{f} 0}\right)$ and after the corresponding treatment $\left(\sigma_{\mathrm{f}}\right)$ were determined during the threepoint bending test of the specimens in air at $20^{\circ} \mathrm{C}$. Based on these data, the relative strength $\left(\sigma_{\mathrm{f}} / \sigma_{\mathrm{f} 0}\right)$ of the material treated was evaluated.

The specific electrical conductivity of the material $(\sigma)$ was determined in air at $20^{\circ} \mathrm{C}$ using the Van der Pauw method. SEM microstructures, microfractographs and quantitative elemental content of the specimens were investigated using the electron microscope Carl Zeiss EVO-40XVP coupled with energy dispersive spectroscopy (EDS) INCA ENERGY 350 .

The X-ray analysis was carried out using DRON-4.0 diffractometer $\left(\mathrm{Fe} \mathrm{K}_{\alpha}\right)$ with Bragg-Brentano-type geometry. The total range of angles was from 20 to 120 degrees. The step was 0.05 degree and total test duration was 8 hours.

The average size of coherent dispersion areas of nickel phase $(D)$ was calculated using the Win CSD program [18]. The spacing between the planes in the atomic lattice $(d)$ of zirconia phase (line 220) was estimated using the Rietveld method [18], and the residual stresses $\left(\sigma_{\mathrm{r}}\right)$ were evaluated using the equation

$$
\sigma_{\mathrm{r}}=-\frac{E}{\mathrm{v}} \cdot \frac{d-d_{0}}{d_{0}}
$$

where $E$ is Young's modulus and $v$ is Poisson's ratio; the values of these parameters were selected according to [19]; $d_{0}$ is the spacing between the planes in the atomic lattice of zirconia phase (line 220) for the as-received material. Thermodynamics of reactions of nickel phase reduction and oxidation was 
analysed by calculating the changes in Gibb's free energy $(\Delta G)$ using standard data [20].

\section{Results and discussion}

Thermodynamics of the Reduction and Oxidation Stages

It is known [21] that in the temperature range $630-680^{\circ} \mathrm{C}$, a transition from diffusion to kinetic mechanism of oxidation occurs. Additionally, by analysing the thermodynamics of reduction and oxidation stages, it was revealed that in the temperature range 600$800^{\circ} \mathrm{C}$, the change in Gibb's free energy $(\Delta G)$ is more negative and the equilibrium constant $(K)$ is considerably higher for the reaction of nickel oxidation compared to its reduction (see Table 2).

Table 2. The data of thermodynamics of reduction and oxidation stages for the material tested

\begin{tabular}{|l|l|l|l|l|}
\hline \multirow{5}{*}{ Reaction } & $\begin{array}{l}\text { Gibb's free } \\
\text { energy } \\
(\Delta G, \\
\mathrm{kJ} / \mathrm{mol}) \text { at } \\
600^{\circ} \mathrm{C}\end{array}$ & $\begin{array}{l}\text { Equilibrium } \\
\text { constant } \\
(K) \text { at } \\
600^{\circ} \mathrm{C}\end{array}$ & $\begin{array}{l}\text { Gibb's free } \\
\text { energy } \\
(\Delta G, \\
\mathrm{kJ} / \mathrm{mol}) \text { at } \\
800^{\circ} \mathrm{C}\end{array}$ & $\begin{array}{l}\text { Equilibrium } \\
\text { constant } \\
(K) \text { at } \\
800^{\circ} \mathrm{C}\end{array}$ \\
\hline Reduction & -41 & $2.7 \cdot 10^{2}$ & -43 & $1.3 \cdot 10^{2}$ \\
\hline Oxidation & -159 & $3 \cdot 10^{9}$ & -145 & $1 \cdot 10^{7}$ \\
\hline
\end{tabular}

According to this, we concluded that during redox cycling at higher temperature, the $\mathrm{Ni}$ oxidation stage becomes more faster than the $\mathrm{NiO}$ reduction one. Thus, the probability of retaining unreduced particles is high, if the reduction period was too short. In such a case, the resulting structure does not meet the requirements on uniformity and, finally, efficiency of an anode substrate.

\section{The Treatment Temperature of $600^{\circ} \mathrm{C}$}

Exposition of YSZ-NiO ceramics at the temperature $600^{\circ} \mathrm{C}$ for $4 \mathrm{~h}$ in the $\mathrm{Ar}-5 \mathrm{vol} \% \mathrm{H}_{2}$ mixture that can be used for gradual reduction of SOFC anodes (version 1 in Table 1) causes partial reduction of the $\mathrm{NiO}$ particles by a diffusion mechanism. Thin $\mathrm{Ni}$ edgings (of thickness of $0.1-0.3 \mu \mathrm{m})$ are formed around $\mathrm{NiO}$ particles (Fig. 3a).

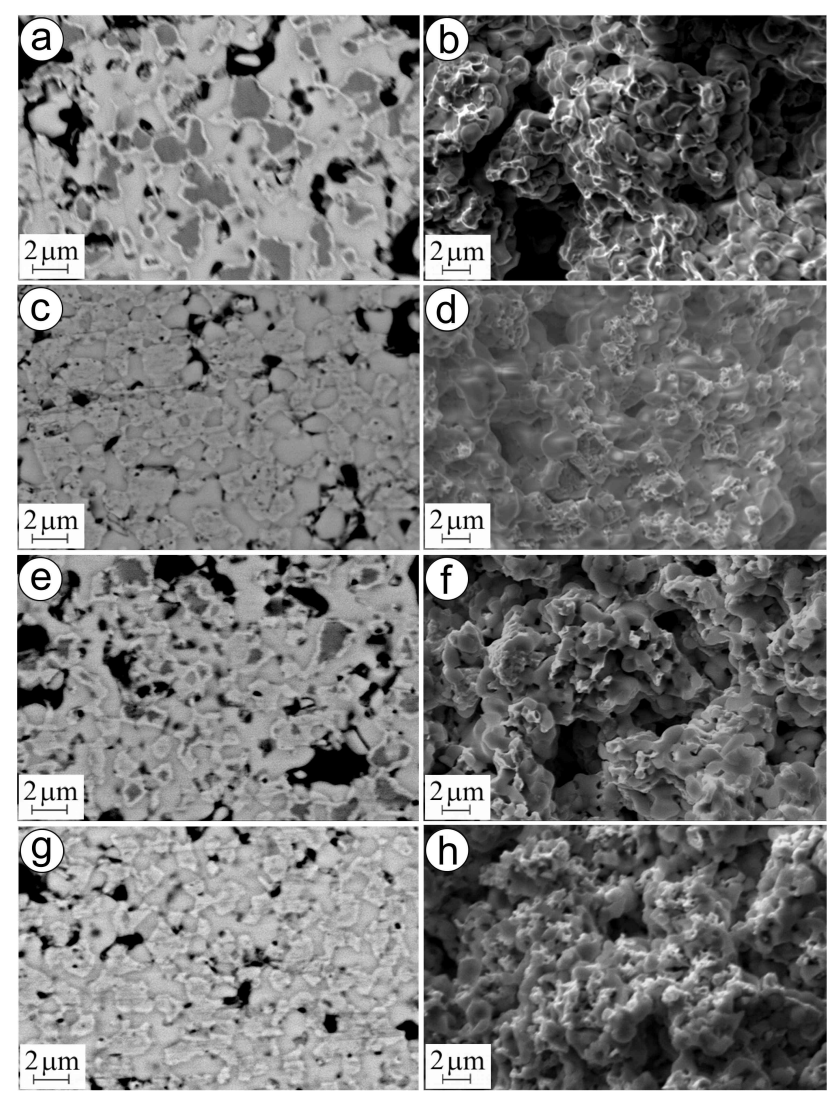

Figure 3. SEM microstructures (a, c, e, g- BSD images) and microfractographs (b, d, f, h-SE images) for the material in versions $1(\mathrm{a}, \mathrm{b}), 2(\mathrm{c}, \mathrm{d}), 3(\mathrm{e}, \mathrm{f})$ and $4(\mathrm{~g}, \mathrm{~h})$ (see Table 1).

The substructure of these edgings was evaluated using X-ray data on average size of coherent dispersion areas of nickel phase $(D)$ (Fig. 4(a)). This parameter was measured as 45 $\mathrm{nm}$. Reduction in strength to $84 \%$ of the value 
for the asreceived YSZ-NiO ceramics (Fig. 4(c)) is possibly caused by partial structural transformation of nickel phase followed by a little volume decrease. It is displayed in the mixed fracture micromechanism (Fig. 3b). Although, no noticeable change of zirconia skeleton was found for this variant of the treatment.

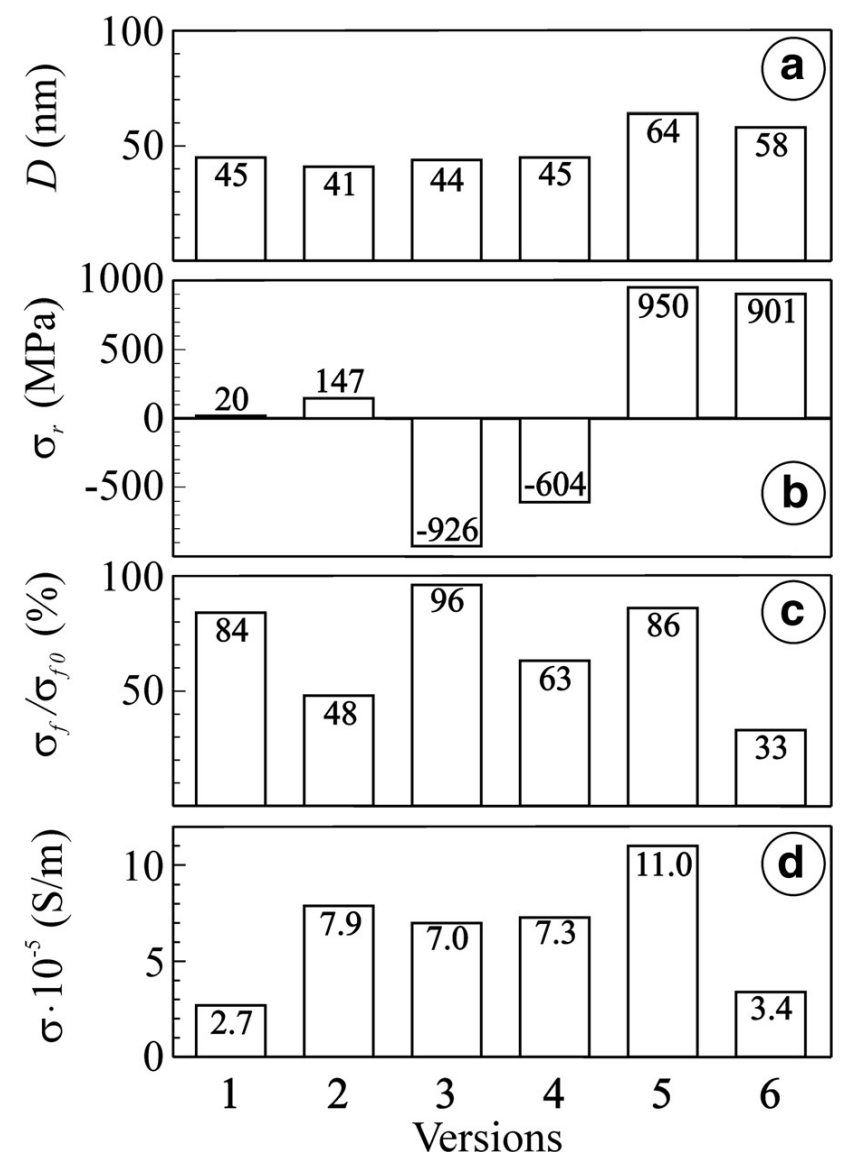

Figure 4. Average size of coherent dispersion area $(D)$ (a), residual stresses $\left(\sigma_{\mathrm{r}}\right)$, in zirconia phase $(\mathrm{b})$, relative strength $\left(\sigma_{\mathrm{f}} / \sigma_{\mathrm{f} 0}\right)(\mathrm{c})$ and specific electrical conductivity $(\sigma)(d)$ for the material in versions 1-6 (see Table 1). The numbers on the bars indicate the values of corresponding parameters.

As compared to the as-received material, residual stresses did not change as well (Fig. 4(b)). The electrical conductivity of the material of $2.7 \cdot 10^{5} \mathrm{~S} / \mathrm{m}$ is provided by thin films of $\mathrm{Ni}$ around $\mathrm{NiO}$ particles united into the network (Fig. 4(d)). More intensive reduction of YSZ$\mathrm{NiO}$ ceramics by the same diffusion mechanism occurs in pure hydrogen (version 2 in Table 1). During $4 \mathrm{~h}$, the structure of completely reduced $\mathrm{Ni}$ particles is formed (Fig. 3c). The substructure parameter (average size $D$ ) of these particles was measured as $41 \mathrm{~nm}$ that is less than for version 1 (Fig. 4(a)). Simultaneously, the volume decrease of initial $\mathrm{NiO}$ particles of $41.6 \%$ occurs [22]. Nanopores on Ni particles formed due to their shrinkage as well as the pores between the particles prevent the rise of residual tensile stresses (Fig. 4(b)).

Nickel phase transformation followed by volume change and formation of pores causes the loss of a significant percentage of particle bonds and violate material integrity which is displayed in the predominantly intergranular fracture micromechanism (Fig. 3d). Reduction in strength to $48 \%$ of the value for the asreceived YSZ-NiO ceramics is recognized (Fig. 4(c)). Thanks to complete reduction of nickel phase, the high electrical conductivity (Fig. 4(d)) of the material is achieved compared to the similar functional materials [23]. According to our data [4], there exists a substantial difference in the mechanical behaviour of $\mathrm{NiO}$ ceramics after redox treatment as compared to that of the singly reduced material, at the treatment temperature of $600{ }^{\circ} \mathrm{C}$. During the 
treatment, structural transformation of boundaries of contacting nickel phase particles occurs, causing an increase in strength. The cleavage fracture micromechanism was noted in the specimens tested. This micromechanism corresponds to the higher cohesive strength of nickel phase particles as compared to the ultimate cleavage stress of the particles themselves. Such treatment technique has been used in this work for improvement of strength and electrical conductivity of YSZ-NiO ceramics. Upon redox cycling, exposition of the material at the temperature $600{ }^{\circ} \mathrm{C}$ for $4 \mathrm{~h}$ in air resulted in complete oxidation of preliminarily reduced $\mathrm{Ni}$ edgings on $\mathrm{NiO}$ particles (version 3 in Table 1, Fig. 3e) as well as of preliminarily reduced $\mathrm{Ni}$ particles (version 4, Fig. 3g) by diffusion mechanism. After five cycles of the redox treatment at $600{ }^{\circ} \mathrm{C}$ with final reduction stage (version 3), most of $\mathrm{NiO}$ particles were reduced completely, forming a continuous network of electrically conducting material in the zirconia skeleton (Fig. 3e) which resulted in the value of specific electrical conductivity of the material of $7 \cdot 10^{5} \mathrm{~S} / \mathrm{m}$ (Fig. 4(d)). Fragmentation of coarse grains of nickel phase resulted in more fine structure of the material treated. The substructure parameter $(D)$ of reduced particles for version 3 was measured as $44 \mathrm{~nm}$ which is similar to that for version 1 (Fig. 4(a)). Thus, no distinct change of substructure of nickel particles was found.
The X-ray data displayed a reduction of $2 \Theta$ angle for cyclically treated materials. In accordance with Wolf-Bragg's law

$$
2 d \sin \Theta=n \lambda
$$

where $n$ is the positive integer and $\lambda$ is the wavelength of incident wave; the spacing between the planes in the atomic lattice $(d)$ of zirconia phase increases resulting (see Eq. (1)) in considerable relaxation of residual stresses $\left(\sigma_{\mathrm{r}}\right)$ in the material of versions 3 and 4 as compared to the as-received material (Fig. 4(b)). This affects positively the mechanical behaviour of the material, especially of version 3 (Fig. 4(c)). The mixed fracture micromechanism was noted in tested specimens of versions 3 (Fig. 3f) and 4 (Fig. 3h). The fracture surfaces comprise brittle cleavage areas of ceramic matrix neighbouring to ductile fracture ones of reduced nickel (Fig. 3f). Like for the $\mathrm{NiO}$ ceramics treated [4], this corresponds to higher cohesive strength between the particles of zirconia and nickel phase as compared to the singly reduced material.

\section{The Treatment Temperature of $800^{\circ} \mathrm{C}$}

In order to reduce the redox treatment duration, the behaviour of YSZ-NiO ceramics was estimated under redox cycling at $800{ }^{\circ} \mathrm{C}$. During single exposition of the material in the $\mathrm{Ar}-5$ vol\% $\mathrm{H}_{2}$ mixture at this temperature (version 5 in Table 1), NiO particles are reduced completely within $1 \mathrm{~h}$ (Fig. 5a) by diffusion mechanism of much higher intensity as compared to version 1 . Reduced Ni particles are 
dotted with nanopores. The $\mathrm{NiO}$ to $\mathrm{Ni}$ transformation is carried out rapidly with formation of comparatively coarse substructure (parameter $D$ of reduced particles was measured as $64 \mathrm{~nm}$, see Fig. 4(a)). The X-ray data display the increase of the $2 \Theta$ angle for the material singly reduced at $800{ }^{\circ} \mathrm{C}$. Consequently, the spacing between the planes in the atomic lattice (d) of the zirconia phase decreases, resulting in considerable growth of residual stresses $\left(\sigma_{\mathrm{r}}\right)$ in the material of version 5 as compared to the asreceived material (Fig. 4(b)). The singly reduced material has somewhat lower strength as compared to as-received ceramics (Fig. 4(c), version 5) but substantially higher electrical conductivity as compared to the material treated at $600{ }^{\circ} \mathrm{C}$ (Fig. 4(d), versions 5 and 1, respectively).

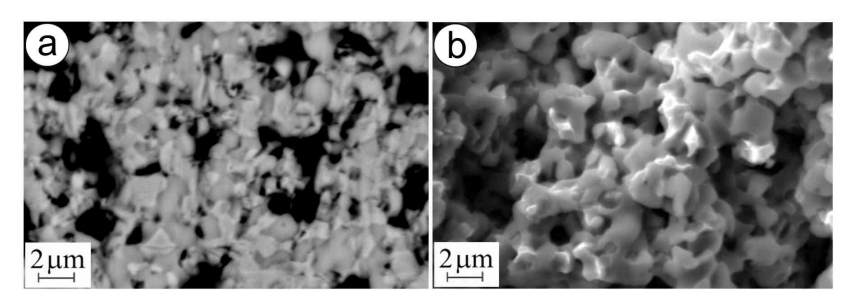

Figure 5. SEM microstructures (a - BSD image) and microfractograph (b-SE image) for the material in version 5 (see Table 1).

The mixed fracture micromechanism is recognized in the specimens tested (Fig. 5b). It is similar to the one after the redox treatment of YSZ-NiO ceramics at $600{ }^{\circ} \mathrm{C}$. It also evidences that single reduction at $800{ }^{\circ} \mathrm{C}$ does not violate the integrity of the zirconia skeleton and a partial decrease in strength is caused by nickel phase transformation.

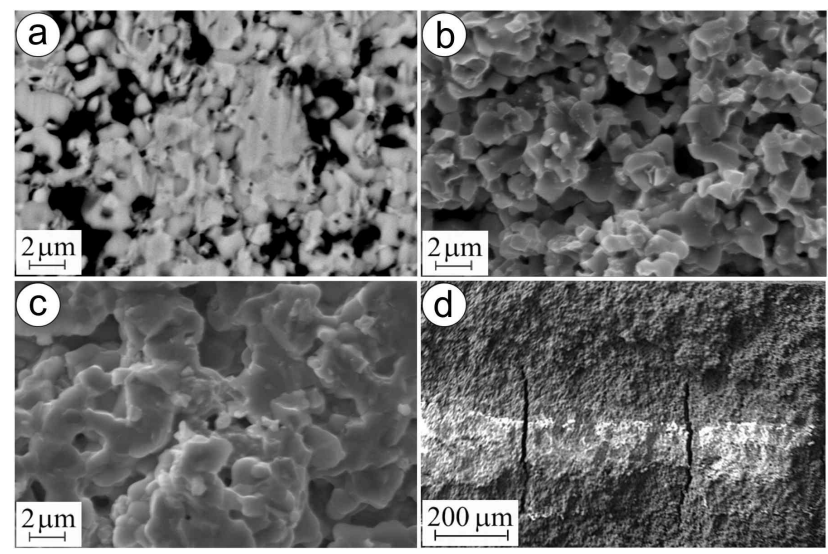

Figure 6. SEM microstructure (a - BSD image) and microfractographs (b-d - SE images) for the material in version 6 (see Table 1).

Contrary to the positive effect of redox treatment of $\mathrm{YSZ}-\mathrm{NiO}$ ceramics at $600{ }^{\circ} \mathrm{C}$, a negative tendency for strength of YSZ-NiO ceramics during the treatment at $800^{\circ} \mathrm{C}$ is noted (Fig. 4(c), version 6). In both cases of the treatment of YSZ-NiO ceramics, the resulting structures are similar (Fig. 6a as compared to Fig. 3e) except for the peculiar (of green colour) inner part of specimens after the treatment at $800{ }^{\circ} \mathrm{C}$ (Fig. 6d).

As stated above, a kinetic mechanism of oxidation at this temperature intensifies the growth of unreduced volume of the anode during redox cycling. Two different areas on the fracture surface picture of a specimen treated at $800{ }^{\circ} \mathrm{C}$ are observed. In the reduced layer, mixed fracture micromechanism comprising transgranular cleavage of zirconia particles and intergranular fracture along the boundaries of contacting nickel phase particles dominates (Fig. 6b). The nickel particles of smaller sizes 
had possibly agglomerated on zirconia particles. Being intact, they are separated by a network of the pores formed during the redox treatment. Thus, this fracture micromechanism is as energy expensive as the one revealed for the material after the redox treatment at $600{ }^{\circ} \mathrm{C}$ (Fig. 3f). In the unreduced inner layer of the anode transgranular cleavage, a fracture of coarse zirconia and nickel oxide agglomerates dominates, and occasionally, the signs of intergranular fracture along the boundaries of particles of smaller size are observed (Fig. 6c). In spite of similar levels of residual stresses in the zirconia phase that were estimated for the entire reduced volume (Fig. 4(b), version 5) and outer reduced layer (version 6), respectively, different structural factors affect the integrity of these materials. The total strength of the material after redox treatment at $800{ }^{\circ} \mathrm{C}$ is decreased considerably with the array of microcracks in the bulk of the specimen (Fig. $6 \mathrm{~d})$ that have formed during the treatment normally to its surface. These microcracks are nucleated following a stress gradient on the boundaries between reduced and unreduced layers as a result of thermal expansion (thermal expansion coefficients for $\mathrm{YSZ}, \mathrm{NiO}$ and $\mathrm{Ni}$ phases are $10.9 \cdot 10^{-6}, 14.1 \cdot 10^{-6}$ and $16.4 \cdot 10^{-6} / \mathrm{K}$, respectively [24]). The reduced layer showed the value of specific electrical conductivity $3.4 \cdot 10^{5} \mathrm{~S} / \mathrm{m}$ (Fig. 4(d), version 6) which is satisfactory for SOFC anodes. However, this value is lower than that of the material singly reduced at $800{ }^{\circ} \mathrm{C}$ (version 5). Besides, the unreduced layer having very low electrical conductivity becomes a substantial obstacle in achieving the required electrochemical performance of the fuel cell. Thus, contrary to the positive effect of redox treatment at $600{ }^{\circ} \mathrm{C}$ on strength and electrical conductivity of YSZ$\mathrm{NiO}$ ceramics, such treatment at $800{ }^{\circ} \mathrm{C}$ causes the formation of anode structure with reduced outer and unreduced inner layers as well as the array of microcracks in the bulk of an anode initiated normally to its surface, what causes the loss of its integrity. The unreduced inner layer of the anode has unsatisfactory electrical conductivity.

Oxidation resistance of MAX-phases at $600^{\circ} \mathrm{C}$ in air

The dependences of weight gain per unit surface area on oxidation time at $600{ }^{\circ} \mathrm{C}$ for $\mathrm{Ti}_{3} \mathrm{AlC}_{2}$ based materials tested are presented in Fig. 7. It can be seen that the $\Delta \mathrm{W} / \mathrm{S}$ for material with porosity of $22 \%$ monotonically increases and reaches the value of $24 \mathrm{mg} / \mathrm{cm}^{2}$ after exposition of $437 \mathrm{~h}$. The rapid oxidation of this material can be explained by intense penetration of oxygen into material through the pores. As a result, not only outer surface of the specimen but also the surfaces of pores in the bulk material were oxidized (Fig. 8a, b).

The oxidation kinetics for $\mathrm{Ti}_{3} \mathrm{AlC}_{2}$ based material with $1 \%$ porosity at $600{ }^{\circ} \mathrm{C}$ remarkable increases on the first stage of the test (Fig. 7). After $15 \mathrm{~h}$ the weight gain per unit surface area 
increases more slowly and after $1000 \mathrm{~h}$ exposition is $1.0 \mathrm{mg} / \mathrm{cm}^{2}$. Table 3 presents an average quantity of chemical elements in bulk material and a film, obtained by EDS method.

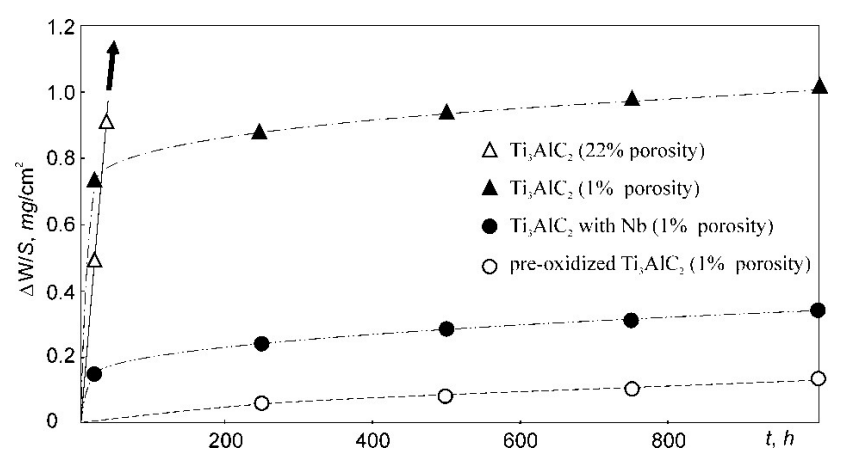

Figure 7. Oxidation kinetics for the MAX-phase at $600{ }^{\circ} \mathrm{C}$ in air

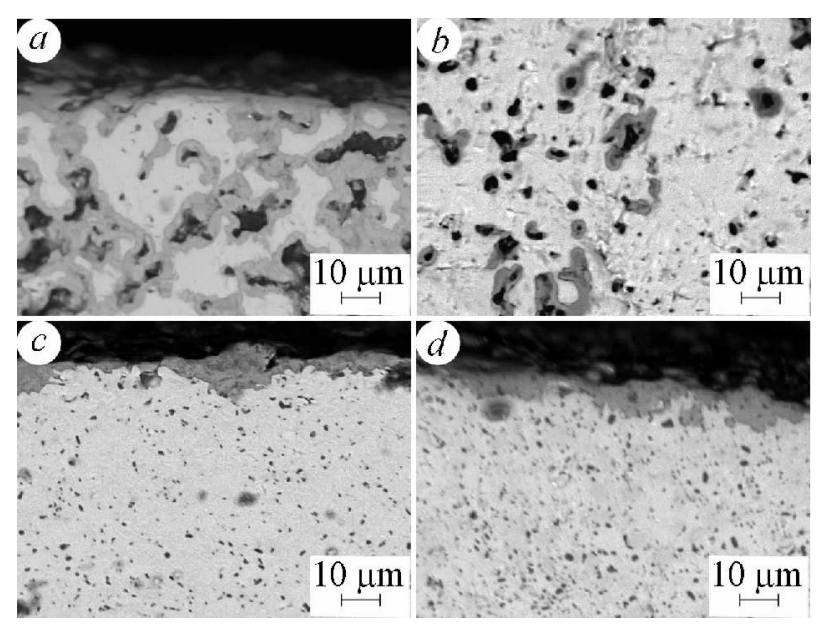

Figure 8. Back-scattered electron images of the films formed at $600{ }^{\circ} \mathrm{C}$ for $1000 \mathrm{~h}$ : (a) $\mathrm{Ti}_{3} \mathrm{AlC}_{2}$ based material with $22 \%$ porosity; (b) oxidized pores of $\mathrm{Ti}_{3} \mathrm{AlC}_{2}$ based material with $22 \%$ porosity; (c) $\mathrm{Ti}_{3} \mathrm{AlC}_{2}$ based material with $1 \%$ porosity; (d) $\mathrm{Nb}$ doped $\mathrm{Ti}_{3} \mathrm{AlC}_{2}$ based material with $1 \%$ porosity.

It can be seen that carbon is missed in the film while oxygen is presented in excessive amounts. This means that the surfaces of $\mathrm{Ti}_{3} \mathrm{AlC}_{2}$ and $\mathrm{TiC}$ particles are completely oxidized to $\mathrm{TiO}_{2}, \mathrm{Al}_{2} \mathrm{O}_{3}$ and gaseous $\mathrm{CO}$ or $\mathrm{CO}_{2}$ phase which volatilizes from the film. The overall equations for the oxidation reactions is,

$4 \mathrm{Ti}_{3} \mathrm{AlC}_{2}+23 \mathrm{O}_{2}=12 \mathrm{TiO}_{2}+2 \mathrm{Al}_{2} \mathrm{O}_{3}+8 \mathrm{CO}_{2}(\mathrm{~g})$,

$\mathrm{TiC}+2 \mathrm{O}_{2}=\mathrm{TiO}_{2}+\mathrm{CO}_{2}(\mathrm{~g})$.

Table 3. EDS analysis results of the $\mathrm{Ti}_{3} \mathrm{AlC}_{2}$ based materials with $1 \%$ porosity (at. $\%$ )

\begin{tabular}{|c|c|c|c|c|c|c|c|c|c|c|}
\hline \multirow{2}{*}{ Materials } & \multicolumn{2}{|l|}{$\mathrm{Ti}$} & \multicolumn{2}{|l|}{$\mathrm{Al}$} & \multicolumn{2}{|l|}{$\mathrm{C}$} & \multicolumn{2}{|l|}{$\mathrm{Nb}$} & \multicolumn{2}{|l|}{$\mathrm{O}$} \\
\hline & $B$ & $\mathrm{~F}$ & B & $\mathrm{F}$ & $B$ & $F$ & B & $\mathrm{F}$ & $B$ & $\mathrm{~F}$ \\
\hline $\mathrm{Ti}_{3} \mathrm{AlC}_{2}$ & 51.3 & 23.7 & 14.8 & 8.1 & 34.6 & 0 & 0 & 0 & 0 & 68.2 \\
\hline $\begin{array}{l}\mathrm{Ti}_{3} \mathrm{AlC}_{2} \\
\text { with } \mathrm{Nb}\end{array}$ & 44. & 25.3 & 14.9 & 3.3 & 42.8 & 0 & 1.4 & 0.6 & 0 & 70.1 \\
\hline
\end{tabular}

$\mathrm{B}$ - bulk material, F - film

Wang and Zhou [14] had demonstrated that the film formed at $600{ }^{\circ} \mathrm{C}$ on the surface of $\mathrm{Ti}_{3} \mathrm{AlC}_{2}$ material with 5 vol. \% TiC consisted of amorphous $\mathrm{Al}_{2} \mathrm{O}_{3}$, anatase and rutile $\mathrm{TiO}_{2}$. The formation of anatase from $\mathrm{Ti}_{3} \mathrm{AlC}_{2}$ led to increase of stress due to the difference of their volume expansion coefficients. Therefore, the rapid increase of $\Delta \mathrm{W} / \mathrm{S}$ value for $\mathrm{Ti}_{3} \mathrm{AlC}_{2}$ based material with $1 \%$ porosity on the first stage of the test can be associated with intense film formation as well as with low protective ability property of the thin film due to microcracks, and also with penetration of oxygen through micropores into bulk material. After long-term exposition, when micropores were covered with oxides and the film thickness was increased (Fig. 8c), the inward diffusion of oxygen and outward diffusion of $\mathrm{Ti}$ and $\mathrm{Al}$ became slowly. As a result the oxidation kinetics was decreased. Based on these results it can be assumed that the preliminary oxidation to form the protective 
layer of oxides would improve the oxidation resistance of $\mathrm{Ti}_{3} \mathrm{AlC}_{2}$ based materials. The preoxidation at $1000-1300{ }^{\circ} \mathrm{C}$ for $2 \mathrm{~h}$ provides the formation of a dense film which consists of $\mathrm{Al}_{2} \mathrm{O}_{3}$ and rutile $\mathrm{TiO}_{2}$ without anatase $\mathrm{TiO}_{2}$ [25]. In present study the pre-oxidation of $\mathrm{Ti}_{3} \mathrm{AlC}_{2}$ based material with $1 \%$ porosity was performed at $1200{ }^{\circ} \mathrm{C}$ in air for $2 \mathrm{~h}$. The longterm oxidation resistance was investigated at $600{ }^{\circ} \mathrm{C}$ in air for $1000 \mathrm{~h}$. As can be seen from Fig. 7 the pre-oxidized material does not demonstrate any discernible increase of weight gain per unit surface area during whole the test. The value of $\Delta \mathrm{W} / \mathrm{S}$ for this material does not exceed $0.11 \mathrm{mg} / \mathrm{cm}^{2}$ after $1000 \mathrm{~h}$ exposition.

The influence of $\mathrm{Nb}$ on the oxidation resistance of $\mathrm{Ti}_{3} \mathrm{AlC}_{2}$ based material with $1 \%$ porosity had been investigated. Despite a greater content of $\mathrm{TiC}$, the weight gain per unit surface area for this material increases more slowly as compared to material without $\mathrm{Nb}$ (Fig. 7). The $\Delta \mathrm{W} / \mathrm{S}$ is $0.34 \mathrm{mg} / \mathrm{cm}^{2}$ after exposition for $1000 \mathrm{~h}$ at $600{ }^{\circ} \mathrm{C}$. This value is approximately 3 times smaller than that for $\mathrm{Ti}_{3} \mathrm{AlC}_{2}$ based material without $\mathrm{Nb}$. Barsoum et al. [26] had shown that $\mathrm{TiC}$ has a deleterious effect on the oxidation kinetics of $\mathrm{Ti}_{3} \mathrm{SiC}_{2}$ based materials which also belong to the isotypic structure $M_{n+1} A X_{n}$. The contradiction of this conclusion with the results obtained in the present work can be explained by positive effect of $\mathrm{Nb}$ on the oxidation resistance of $\mathrm{Ti}_{3} \mathrm{AlC}_{2}$ based material. The EDS analysis shows that the content of $\mathrm{Ti}$,
$\mathrm{Al}$ and $\mathrm{Nb}$ in the film of $\mathrm{Ti}_{3} \mathrm{AlC}_{2}$ based material with $\mathrm{Nb}$ is less than that in the bulk material (Table 3). On the other hand, the content of $\mathrm{Al}$ in the film of this material is significantly less than that of material without $\mathrm{Nb}$. Therefore, it is reasonable to assume that the film of $\mathrm{Ti}_{3} \mathrm{AlC}_{2}$ based material with $\mathrm{Nb}$ consists mainly of $\mathrm{TiO}_{2}$ and of minor quantity of $\mathrm{Al}_{2} \mathrm{O}_{3}$ (Fig. 8d). According to [12], the formation of dense $\mathrm{Al}_{2} \mathrm{O}_{3}$ layer is responsible for high oxidation resistance of $\mathrm{Ti}_{3} \mathrm{AlC}_{2}$ based materials. Thus, the material with $\mathrm{Nb}$ ought to be less oxidation resistant than material without $\mathrm{Nb}$. Jiang et al. [27] had concluded that $\mathrm{Nb}$ in solid solution with $\mathrm{TiO}_{2}$ improves the oxidation resistance of $\mathrm{Ti}-\mathrm{Al}-\mathrm{Nb}$ alloys by impeding mass transformation in $\mathrm{TiO}_{2}$. Evidently in case of $\mathrm{Ti}_{3} \mathrm{AlC}_{2}$ based materials the positive effect of $\mathrm{Nb}$ manifests in the same manner.

\section{Conclusions}

A cyclic treatment technique (redox cycling) comprising stages of material exposition in reducing and oxidizing hightemperature gas environments and intermediate degassing between these stages has been developed to improve the strength and electrical conductivity of YSZ-NiO ceramic anode substrates for solid oxide fuel cells. Based on the experimental data, we suppose that redox cycling at $600{ }^{\circ} \mathrm{C}$ is the most ideal for this material. The parameters of the treatment (reduction dwell time not less than $4 \mathrm{~h}$ under the pressure of the Ar-5 vol\% H2 mixture of 0.15 
$\mathrm{MPa}$; oxidation dwell time $4 \mathrm{~h}$ ) allow a structure to be formed which provides improved physical and mechanical properties of the material. In such a structure, according to the X-ray analysis, a substantial drop of residual stresses is achieved as compared to the one-time reduced material.

The oxidation resistance of MAX-phase based materials had been studied at $600{ }^{\circ} \mathrm{C}$ in static air for $1000 \mathrm{~h}$. The results showed that the weight gain per unit surface area for sintered $\mathrm{Ti}_{3} \mathrm{AlC}_{2}$ based material with porosity of $22 \%$ increased gradually and after $437 \mathrm{~h}$ reached the value of $24 \mathrm{mg} / \mathrm{cm}^{2}$. The drastic increase of oxidation kinetics of this material was caused by intense oxidation not only the outer surface of specimen but also the surfaces of pores. The weight gain per unit surface area for hot pressed $\mathrm{Ti}_{3} \mathrm{AlC}_{2}$ based material with $1 \%$ porosity intensively increased for the first $15 \mathrm{~h}$ of oxidation and then the oxidation kinetics slowly decreased. The pre-oxidation at $1200{ }^{\circ} \mathrm{C}$ for $2 \mathrm{~h}$ eliminated the initial oxidation of this material at $600{ }^{\circ} \mathrm{C}$. It was revealed that the additional doping with $\mathrm{Nb}$ significantly improves the oxidation resistance of $\mathrm{Ti}_{3} \mathrm{AlC}_{2}$ based material.

\section{References}

[1] Sarantaridis D, Atkinson A. Redox cycling of Ni-based solid oxide fuel cell anodes: a review. Fuel Cells 2007; 3:246-258

[2] Ettler M, Timmermann H, Malzbender J et al. Durability of Ni anodes during reoxidation cycles. J. Power Sources 2010; 195:5452-5467
[3] Wood A, Waldbillig D. Preconditioning treatment to enhance redox tolerance of solid oxide fuel cells. United States patent 20118029946 B2. 2011 Oct 4.

[4] Podhurs'ka VY, Vasyliv BD, Ostash OP et al. Structural transformations in the NiO-containing anode of ceramic fuel cells in the course of its reduction and oxidation. Materials Sci 2014; 49(6):805-811

[5] Ostash OP, Vasyliv BD, Podhurs'ka VY et al. Optimization of the properties of $10 \mathrm{Sc} 1 \mathrm{CeSZ}-\mathrm{NiO}$ composite by the redox treatment. Materials Sci 2011; 46(5):653-658

[6] Vasyliv BD, Podhurs'ka VY, Ostash OP et al. Influence of reducing and oxidizing media on the physicomechanical properties of ScCeSZ-NiO and YSZ$\mathrm{NiO}$ ceramics. Materials Sci 2013; 49(2):135-144

[7] Radovic M, Barsoum MW (2013) MAX phases: bridging the gap between metals and ceramics. Amer Ceram Soc Bull 92(3):20-27

[8] Barsoum MW, Yoo H-I, Polushina IK et al. (2000) Electrical conductivity, thermopower, and Hall effect of $\mathrm{Ti}_{3} \mathrm{AlC}_{2}, \mathrm{Ti}_{4} \mathrm{AlN}_{3}$, and $\mathrm{Ti}_{3} \mathrm{SiC}_{2}$. Phys Rev 62(15):1094-1098

[9] Prikhna T, Cabioc'h T, Gawalek W et al. (2014) Study of thermal stability and mechanical characteristics of MAX-phases of Ti-Al-C(N) system and their solid solutions. Advan Sci Technol 89:123-128

[10] Barsoum MW, Tzenov N, Procopio A et al. (2001) Oxidation of $\mathrm{Ti}_{\mathrm{n}}+{ }_{1} \mathrm{AlX}_{\mathrm{n}}(\mathrm{n}=1-3$ and $\mathrm{X}=\mathrm{C}$, N): II. Experimental Results. J Electrochem Soc 148(8):551-562. doi:10.1149/1.1380256

[11] Song GM, Pei YT, SloofWG et al. (2008) Early stages of oxidation of $\mathrm{Ti}_{3} \mathrm{AlC}_{2}$ ceramics. Mater Chem Phys 112:762-768

[12] Wang XH, Zhou YC (2003) Oxidation behavior of $\mathrm{Ti}_{3} \mathrm{AlC}_{2}$ at $1000-1400{ }^{\circ} \mathrm{C}$ in air. Corros Sci 45:891-907

[13] Taotao A (2012) High-temperature oxidation behavior of un-dense $\mathrm{Ti}_{3} \mathrm{AlC}_{2}$ material at $1000{ }^{\circ} \mathrm{C}$ in air. Ceram Int 38:2537-2541 
[14] Wang XH, Zhou YC (2003) Oxidation behavior of TiC-containing $\mathrm{Ti}_{3} \mathrm{AlC}_{2}$ based material at 500-900 ${ }^{\circ} \mathrm{C}$ in air. Mat Res Innovat 7:381-390. doi:10.1007/s10019-003-0278-7

[15] Pang WK, Low IM, O’Connor BH et al (2009) Oxidation characteristics of $\mathrm{Ti}_{3} \mathrm{AlC}_{2}$ over the temperature range $500-900^{\circ} \mathrm{C}$. Mater Chem Phys 117:384-389

[16] Podhurska V, Vasyliv B. Influence of redox treatment temperature on microstructure and properties of $\mathrm{Ni}-\mathrm{ZrO}_{2}$ anode materials. Proceedings of the International Conference on Oxide Materials for Electronic Engineering (OMEE-2014); 2014, May 26-30; Lviv, Ukraine. Lviv, Publishing House of Lviv Polytechnic; 2014.

[17] Tikekar N, Armstrong T, Virkar A. Reduction and reoxidation kinetics of Ni-based SOFC anodes. J. Electrochem. Soc 2006; 153:A654-A663

[18] Akselrud LG, Zavalii PY, Grin YN et al (1993) Use of the CSD program package for structure determination from powder data. Mat Sci Forum 133:335342. doi:10.4028/www.scientific.net/MSF.133-136.335

[19] Sun B, Rudkin RA, Atkinson A. Effect of thermal cycling on residual stress and curvature of anode-supported SOFCs. Fuel Cells 2009; 6:805-813

[20] Mills I, Cvitas T, Homann K et al. Quantities, units and symbols in physical chemistry. Oxford: BLACKWELL SCIENCE LTD.; 1993, pp.1-165.

[21] Peraldi R, Monceau D, Pieraggi B. Correlations between growth kinetics and microstructure for scales formed by high-temperature oxidation of pure nickel. I. Morphologies and microstructures. Oxid. Met 2002; 58:249-273

[22] Faes A, Nakajo A, Hessler-Wyser A et al. Redox study of anode-supported solid oxide fuel cell. J. Power Sources 2009; 193:55-64

[23] Zhang Y, Liu B, Tu B et al. Redox cycling of $\mathrm{Ni}-\mathrm{YSZ}$ anode investigated by TRP technique. Solid State Ion 2005; 176:2193-2199
[24] Mori M, Yamamoto $\mathrm{T}$, Itoh $\mathrm{H}$ et al. Thermal expansion of nickel-zirconia anodes in solid oxide fuel cells during fabrication and operation. J. Electrochem. Soc 1998; 145:1374-1381

[25] Wang XH, Zhou YC

Improvement of intermediate-temperature oxidation resistance of $\mathrm{Ti}_{3} \mathrm{AlC}_{2}$ by pre-oxiadtion at high temperatures. Mat Res Innovat 7:205-211. doi:10.1007/s10019-033-0252-4

[26] Barsoum MW, El-Raghy T, Ogbuji LUJT (1997) Oxidation of $\mathrm{Ti}_{3} \mathrm{SiC}_{2}$ in air. $\mathrm{J}$ Electrochem Soc 144:2508-2516. doi: $10.1149 / 1.1837846$

[27] Jiang H, Hirohasi M, Lu Y et al. (2002) Effect of $\mathrm{Nb}$ on the high temperature oxidation of $\mathrm{Ti}-(0$ 50 at. \%)Al. Scripta Mater 46:639-643 